Peer-Reviewed Article
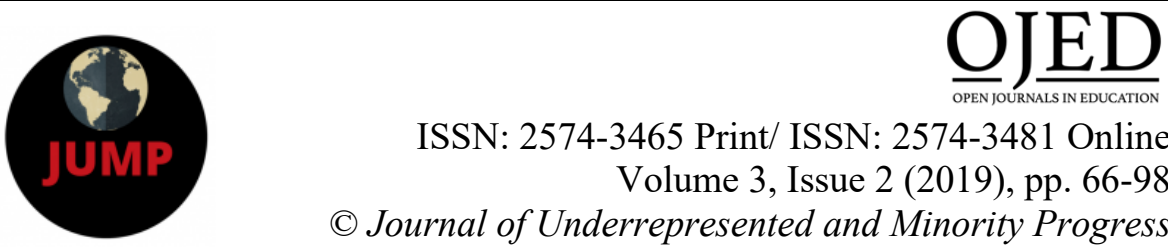

ISSN: 2574-3465 Print/ ISSN: 2574-3481 Online

Volume 3, Issue 2 (2019), pp. 66-98

(C) Journal of Underrepresented and Minority Progress

http://ojed.org/jump

\title{
Issues Faced by American Institutions of Higher Education as They Seek to Design and Implement Affirmative Action Plans: Current Admissions and Faculty/Staff Hiring Policies and Practices
}

\author{
Angel Wazin \\ Morgan State University, USA.
}

\begin{abstract}
This article provides an overview of opposing perspectives on affirmative action and makes a case for affirmative action on the grounds of diversity and from the perspective of a necessity to remedy past discrimination (Hasnas, 2018; Wright \& Garces, 2018; Kaplin \& Lee, 2013). My argument employs Hurtado, Milem, Clayton-Pedersen, and Allen's (2010) four (4) dimensions of educational programs and practices needed in assessing diversity in the institution: historical legacy of inclusion/exclusion of racial/ethnic groups; structural diversity regarding numerical representation; the psychological climate of perceptions and attitudes; and the behavioral climate dimension. Additionally, because the expressed consideration of race and gender in admissions and hiring processes have legal implications, I provide legal guidelines and precedents to mitigate litigation.
\end{abstract}




\section{INTRODUCTION}

The battle for equality and equity for minorities in higher education is a longstanding one. Affirmative action policies, designed to increase the number of people from groups historically underrepresented in institutions, present intricate debates socially, pedagogically, and legally.

Affirmative action policies are probably the most polarizing current public debate in America (Kaplin \& Lee, 2014; Schuck, 2002). Today, the Trump administration is removing Obama-era guidance, which encouraged schools to consider students' race to promote diversity in admissions. The affirmative action policies are being rescinded by the Justice Department for being "unnecessary, outdated, inconsistent with existing law, or otherwise improper" (Associated Press Report, 2018, para.1).

This move is worrisome; it sends a signal that the administration opposes the practice of race-conscious admissions, and it has encouraged detractors of affirmative action (Nguyen, 2019; Thomason, 2018; Miller, 2019). As stated by Ted Mitchell, president of the American Council on Education, it sends the wrong message to institutions dedicated to following four decades of Supreme Court precedents (as cited in Thomason, 2018). With this shift, the federal government gives colleges and universities a green light: Take a race-neutral approach in admissions and hiring decisions.

In this article, following an overview of opposing perspectives on affirmative action, a case is made for affirmative action. The argument is twofold: first, affirmative action can be proposed on the grounds of diversity; and second, it can also be defended as a necessity to remedy past invidious discrimination (Hasnas, 2018; Wright \& Garces, 2018; Kaplin \& Lee, 2013). While the struggles of all minorities, including those based on sexual orientation and disability, obviously should be acknowledged and respected, this article examines race and gender (women).

The argument for affirmative action is conceptualized based on the four dimensions of educational programs that Hurtado, Milem, ClaytonPedersen, and Allen (2010) propose as essential when we assess diversity in the institution. These are:

1. the historical legacy of inclusion or exclusion of various racial/ethnic groups;

2. structural diversity arising from issues of numerical representation of various racial/ethnic groups;

3. the psychological climate of intergroup perceptions and attitudes; and 
4. the behavioral climate that is defined by intergroup relations on campus.

Additionally, since race and gender in admissions and hiring processes may precipitate legal implications, guidelines and precedents are examined which mitigate the possibility of litigation arising that rests upon the claim of "reverse discrimination" by non-minority individuals (Kaplin \& Lee, 2014).

\section{AFFERMATIVE ACTION CONTROVERSIES}

Different perspectives swirl around the affirmative action policy debate on admissions and hiring processes in higher education. According to Wright and Garces (2018), there are three major perspectives on the controversies of affirmative action: color-blindness, race neutrality, and color-consciousness.

\section{The color-blind perspective}

According to the color-blind perspective, race should never matter, and it is never necessary to increase racial equity. Proponents of this approach believe that the problem with race relations in America is that too much power is given to a man-made construct by continuously acknowledging it. They propose that the best way to get "beyond racism" is to create policies and procedures that do not consider race for anyone or for any reason. Supporters of color blindness make three arguments (Wright \& Garces, 2018).

First, in states including California, Florida, Texas, Washington, Arizona, Michigan, Nebraska, New Hampshire, and Oklahoma, where taking race into account has been banned through ballot initiatives or other measures (Backes 2012; Hinrichs 2012, Hinrichs, 2014), proponents of color blindness claim the diversity of the student body has not changed.

Second, when talking about elite schools, they endorse the mismatch theory. This maintains that race conscious admissions are harmful to students of color because they are "overmatched" in environments that are too competitive for their individual needs. The theory not only attacks race-based admissions but also the idea of "holistic" review, since its premise is that test scores should be the ultimate determining factor in college admissions.

Third, proponents of color blindness believe that the future of the law is on their side (Wright \& Garces, 2018). The court, in a 2003 case known as Grutter (discussed later in this article), predicted that in 25 years, societal conditions would have progressed to the extent that there would be no need for such policies (Kaplin \& Lee, 2018). Today, just eight years shy of that 25 
year mark, some color-blind proponents ask, if we truly want to be color blind in the future, why not start by being color blind right now (Wright \& Garces, 2018, p. 12)?

\section{The race-neutral perspective}

The race-neutral perspective argues that the consideration of race is unnecessary if other characteristics can be used to yield as much or even more diversity. It thus advocates for racial equity, but it does so through means that are free of the expressed use of race.

Here, admission decisions are made without explicit consideration of race. Instead, proxies of race are to be used to obtain the level of diversity needed to yield the educational benefits of diversity; all students should qualify for these admissions "assists," regardless of race (Wright \& Garces, 2018). Why not use socioeconomic status (Kahlenberg \& Potter, 2014); geography and wealth (Cashin, 2014); or a "disadvantaged index" based on parental income and education? Why not enter applicant names into a lottery based on a specified criterion of scores (Hurtado et al., 2010)?

Wright and Garces (2018) describe the race-neutral perspective as an "umbrella." It is used by those who support race neutrality, because their intent is color blindness, but they see this as a subtler way to achieve their goals.

And then there are those who would otherwise support colorconsciousness, but they view this as a less controversial compromise, one that could yield approximately the same levels of diversity. Unlike color-blind proponents, these race-neutral supporters believe that a certain level of ethnic or racial diversity is central to the learning process and to creation of a proper college environment.

\section{The Color-Conscious Perspective}

The color-conscious perspective posits that the use of race is necessary if we are to address racial inequities that exist today. How race should be considered depends on the institutional context, but it involves a holistic admissions process that considers race as one of many factors. For example, an institution adopting this approach would take as a "plus factor" the race/ethnicity of an applicant whose minority group is underrepresented on campus just as it would consider the fact that a student plays piano or speaks several languages positively. Color-conscious supporters do not argue that race should be the only criterion. Rather it should be one of many such criteria. They also believe that there is a need for an equalizing factor, due to the unequal conditions of racial groups (Wright \& Garces, 2018). 


\section{THE FOUR DIMENSIONS OF INSTITUTIONAL DIVERSITY}

\section{Historical Legacy}

As stated by Hurtado et al. (2010), the historical vestiges of segregated institutions continue to affect the climate for racial/ethnic diversity on campus in many ways. While some colleges and schools have granted admissions and graduated students of color since their founding days, most predominantly white institutions have a history of limited access and exclusion. The history of higher education in America enlightens us that the explicit function of the university was to operate within (and in service to) the new colonial establishment. Created to educate the offspring of colonizers, the colonial university acted as a preserver of social inequality by only serving white elite males (Thelin, 2004). While the educational system was built to serve whites, minorities were used to fund and maintain the colleges (Wilder, 2013).

In the early $1600 \mathrm{~s}$, the colonial elites began to use Native Indians to lobby for finances in England. While the elites raised funds for their colleges through supposed special interests in the civilization of native Indians, they educated few Indian students. The elites also funded the colonial colleges with proceeds from the sale of black slaves. Blacks were not students, but they were central to the colleges' operations. Slaves outnumbered faculty, administrators, and trustees on many Ivy League campuses. For example, Dartmouth College had more slaves than it did students. Enslaved blacks provided the free labor needed to erect buildings and maintain the grounds of campuses, as well as cook and clean dormitories (Wilder, 2013).

Black bodies were used for experiments and regarded as inferior to whites. Blacks were psychologically abused and traumatized as men like Louis Agassiz and Samuel George Morton theorized blacks as constituting a degraded and degenerate race. Blacks were characterized as the least of the humans; black skin was synonymous with leprosy, their physical features and genitals likened to apes (Watkins, 2001). On college campuses, blacks were whipped, dismembered, sexually assaulted, and sold, which disrupted family units. These actions resulted in emotional trauma, leading some blacks to commit suicide (Wilder, 2013).

Blacks were bought by and gifted to college presidents, many of whom were slave masters. For example, Harvard's president Increase Mather's (1692 to 1701) son, Cotton Mather (class of 1678), gifted him with an enslaved man, whom he used "to run errands for the college" (Wilder, 2013, p. 119). Another president, Benjamin Wadsworth, owned an enslaved 
black man called Titus, who lived with the president's family. Benjamin Franklin, founder of the College of Philadelphia; the first eight presidents of the College of New Jersey (Princeton); and Georgetown presidents Fathers Louis William Valentin DuBourg (1796-1798) and Stephen L. Dubuisson (1825-1826), were all slave owners, people who accumulated enslaved blacks for their personal service throughout their tenures as college administrators (Wilder, 2013).

The colonial colleges were entertained through enslaved blacks' humiliation and suffering. For example, several white male college students seeking recreation at Harvard forced the intoxication of an enslaved Black man almost unto death. One of the perpetrators was John Hancock, who would go on to be governor and signer of the Declaration of Independence. The rest of those men became ministers, doctors, and lawyers. At one of the Yale campuses, the early students raped black women so frequently that the college removed the women from the students' presence, leaving the cook whom the students also terrorized. At Williams College, a black man was forced to smash his head into wooden boards and barrels. Enslaved people at the University of North Carolina were frequently subjected to "pranks." For example, in 1811, students went running wild while attacking their black servants (Wilder, 2013).

While most of the gruesome and horrendous stories of injustice towards blacks are omitted from the history of powerful institutions, especially those in the Ivy League, with the recent deep discussions of racism some of these slavery connections are being unearthed. For example, Georgetown University reports, "beginning with deliberations in the 1780s over the founding of an academy and until the end of the Civil War, Georgetown University's origins and growth, and successes and failures, can be linked to America's slave-holding economy and culture" (as cited in Eckel \& Trower, 2016, p. 14).

Considering the role that minorities played in the operation and funding of the colonial colleges, and the unjust and inhumane treatments of blacks, there is a compelling case for granting blacks access to these institutions. Blacks are still striving for access to higher education, while their white counterparts often have resources that place them at an advantage. Hence, race-conscious affirmative action programs are still necessary today to serve as equalizing factors to help level the playing field for minorities.

\section{Today's Structural Diversity: Students}

According to Hurtado et al. (2010), one way of improving the diversity of a campus is through increasing representatives from a wider 
variety of groups. While African Americans and Latinos are attending colleges, and receiving more degrees than before, they continue to be proportionally underrepresented in higher education when we consider the traditional college-age population (Newkirk, 2019; Quinlan, 2016; Eckwel \& Trower, 2016, Harper \& Quaye, 2015; Henrichs, 2014; Prescott \& Bransberger, 2012; Perna, 2000). According to a United Negro College Fund (UNCF, 2017) report, a 2015 study showed that only 23 percent of African Americans had earned a four-year college degree, about 40 percent less than white Americans.

Admission requirements and funding are two major challenges to minority students. For example, in the 2016-2017 school year, the Pell Grant program -- the single largest source of federal scholarships for students who lack the financial means to pay for college -- paid an average Pell award of $\$ 5,815$. This amount accounts for only 29 percent of the cost of attending a four-year public college and only 13 percent of the cost of attending a fouryear private nonprofit college -- the lowest share in the history of the program (UNCF, 2017).

Graduate/professional admission policies and practices at selective institutions place high importance on standardized test scores and too little on previous achievements evidenced in high school or college GPAs. These tests pose great obstacles for students with disadvantaged backgrounds. They do not have the same opportunities as their white counterparts, who are frequently from affluent families with greater and better access to education, living in communities with better funding and more educational resources (Hurtado, 2010). Schmidt (2013) points out that in addition to minorities' lack of cultural and social capital, admission standards are often bypassed for rich white students due to financial gains from family donors, politicians, and alumni.

Because of the unfairness of the system and the disproportion of resources between minorities and their white counterparts, it is necessary for institutional policy to provide access to underrepresented minorities through areas of admissions practices and financial aid.

In a society where education plays a pivotal role in earning potential, degree attainment is important. A UNCF report showed that "a substantial proportion (77 percent) of low-income, African American parents believe it is important for their children to attend and graduate from college" (UNCF, 2017, p. 5). Minorities need to be given the opportunity to obtain a degree, because people with higher levels of education then earn more and have a better chance than others at being employed today (Wright \& Garces, 2018). 
Giving minority students a nudge to get their foot in the door, to help increase their chance at economic success and meaningfully contribute to society, should not be viewed as giving them special treatment or seen as unfair to their white counterparts, because it is the same system (orchestrated by white privileged policy makers) that laid the uneven and shaky foundation for minorities but very leveled and firm foundation for whites in the academy.

Hence, it is only fair that institutions acknowledge and seek to address the role that racism has played historically, and the continuing ripple effects being felt today by minorities in the academy. Furthermore, institutions must be intentional about addressing this issue, because there is no going beyond race or substituting race -- it remains integral in the lived experiences of minority students.

\section{Structural Diversity: Faculty/Staff}

It is argued that minority faculty are typically hired in token numbers in most departments. Tokenism creates environments where professors become one of the few, if not the only person of color, in their departments (Blackwell, 1988).

Structural racism is manifested in several ways, including persistent underrepresentation of black professors in academe (Griffin, Pifer, Humphrey \& Hazelwood, 2011). A study conducted in 2003 showed that black professors comprised of about eight percent of faculty at public master's colleges and approximately seven percent of faculty at two-year colleges, but they constituted only 4.3 percent of full-time faculty at public doctoral institutions and 4.7 percent at private doctoral institutions (Cataldi, Bradburn, Mansour \& Zimbler, 2005). Another study in 2005 showed that although African Americans represented 14 percent of the American population and 12 percent of all undergraduates, only 6 percent of all professors were African American. When examined by institutional type, those results reduced and showed specific underrepresentation of black faculty at research universities (Ryu, 2008).

Another issue of representation in higher education is gender disparity. It is argued that "the academy is anchored in assumptions about competence and success that have led to practices and norms constructed around the life experiences of men, and around a vision of masculinity as the normal, universal requirement of university life" (Bailyn, 2003, p. 143).

Although women receive a little more than 50 percent of the Ph.D.'s awarded by American universities, most women do not obtain jobs at the more prestigious and higher-paying research universities where they earned their degrees. Women are most well represented at community colleges (with 
and without academic ranks) and least well represented at doctoral-level institutions. Women make up 50 percent of the faculty at community colleges, 41 percent at baccalaureate and master's degree colleges, and 33 percent at doctoral-level universities. Women are greatly overrepresented below the tenure track in the low-paying, non-tenured positions. They make up 58 percent of instructors and 54 percent of lecturers, and they hold 51 percent of unranked positions (Mason, 2011).

Trevino, Balkin, and Gomez (2017) posit to "undo" gender and to make substantial and lasting changes in gender balance in the academy, there must be a continuous challenge to the assumption that existing processes for judging faculty and for promotion and tenure are gender-neutral. Ridgeway (2007) states that the expectations and beliefs associated with gender is instrumental in organizing the social relations within which advancement decisions take place.

Seeing women and racial/ethnic minorities in the role of professor is effective in breaking down unfair stereotypes. Additionally, having women and minorities in the academy does not only provide intellectual mentors and models for underserved students, but it also fosters mutual respect and calls for students to communicate in a respectful and effective manner with people from different backgrounds.

Moreover, a diverse faculty group boosts the overall quality of academic scholarship (Hasnas, 2018). Kennedy (1990) states when individuals of underrepresented communities are excluded from university faculty, scholarly contributions are limited to a small number of people connected to those communities. Diverse faculty members bring a variety of perspective, experience, knowledge, debates, and academic writing styles (Kennedy, 1990; Johnson, 2011). Statistics show that there is a paucity of minority faculty and staff, but with the educational benefits arising from diversity, there is a need to promote the hiring of minorities not only for representation, but also for inclusion.

As Ahmed (2012) states so powerfully, representation can be a lesson in "being not" as much as "being in" (p. 163). Considering the historical exclusion of black and women professionals in the academy, affirmative action hiring policies would not only create an environment where black and other minority students are taught by faculty who look and sound like them but would also give a hand up to minority scholars who are often stuck on the first rungs of the ladder. As the struggle to close the gap between disadvantaged minorities and the advantaged whites continue, it is important for minorities, whose cultural and social capital are at a consistent deficit, to be granted access. This would increase mentorship opportunities and help 
other minority groups to navigate the academy as well as help in their professional development, expanding their professional network and increasing advocacy. Hence, affirmative action policies are not outdated but are still needed today.

\section{Racial Climate: The Psychology and Behavior of Students}

According to Hurtado et al (2010), a campus racial climate is reflective of the attitudes, perceptions, and expectations within an institutional community regarding issues of race/ethnicity and diversity. The psychological dimension of the campus racial climate consists of individual views of group relations, institutional responses to diversity, perceptions of discrimination or racial conflict, and one's attitudes toward people of different racial/ethnic backgrounds. The behavioral dimension consists of actual reports of general social interaction among individuals from different racial/ethnic backgrounds, and the nature of intergroup relations on campus.

To gauge the climate of US campuses and how they support diversity, Hurtado and Ruiz (2012) investigated findings from the Diverse Learning Environments National Survey (DLE), which was designed to assist institutions of higher learning in evaluating their campus racial climate. The DLE sample included 31 private and public institutions that were different as relates to minority enrollment policies, including public institutions in California and Texas that no longer use race as a factor in enrollment decisions.

The results showed that only thirteen percent of minority students reported racial incidents to their university officials, and that racial conflicts occurred at a significantly higher rate at low-diversity institutions. In addition, 55.4 percent of black students reported some level of exclusion, and 60.4 percent of minority students indicated that the most prevalent form of discrimination came in the form of racist verbal comments at low-diversity institutions. The percentage of black students who experienced offensive verbal comments at low-diversity institutions was the highest among students of all races and ethnicities with 67.2 percent, whereas 58.8 percent of Hispanic students reported similar experiences at low-diversity institutions. These results decreased significantly at the most diverse institutions where campus racial climates were more hospitable (Hurtado \& Ruiz, 2012).

According to Quinlan (2016), a huge challenge for black students at predominantly white institutions is failing to get solidarity from the administration. According to Basinger (2016), a majority of protests on campus are centered on student complaints about systematic racism, although there have been complaints about gender identity and other concerns have 
also appeared. Another challenge of black students is confronting racial bias from professors and peers. Black students must fight assumptions about their competence and their interests from their teachers and fellow students.

Additionally, it is more difficult for black students to find mentors. Researchers at New York University, Columbia University, and the University of Pennsylvania found that when students contacted professors for mentorship, faculty were significantly more responsive to white men than to women or to people of color. This was particularly true in private universities and in the higher-paying disciplines. Students of color reported that they often felt isolated from the larger student population and that their white peers were not readily willing to share information with them. Their white counterparts assumed that they were undeserving of their place at the university and were trying to "piggy-back" off the work of white students work (Quinlan, 2016).

Hurtado et al. (2010) state that there is a need for institutions to show that social interaction, and interaction between individuals from different ethnic/ racial backgrounds, are highly valued. One way to do so is to develop programs to promote such behaviors in the representation of diverse others. Faculty can assist in the behavioral dimension through promoting interaction of different students through cooperative learning activities (inside and outside of classroom), increasing interaction across race and intergroup friendships. Again, because minorities have been historically excluded in higher education, it is difficult for them to be perceived by their white counterparts as belonging and equal to, hence it takes intentional efforts, even with comparable or exceeding academic performance, to create a welcoming and receptive atmosphere which would begin with having access in the first place.

But it does not end there. Minority students being viewed as "mismatched" to selective college environments (as the color-blind proponents claim) or not being up to par with the caliber of white students dominating these spaces, is not a question of minorities' intellect or capabilities- it is in fact a racial issue. When it is ingrained in a person that one is less than or inferior to because one is black, or on the flip side, that one is better than or superior to others because one is white, then it only becomes natural to view oneself and others through that genetic hierarchical lens.

Hence, affirmative action policies increasing the representation of others and introducing new cultures and perspectives help to improve the campus climate. These policies offer fresh perspective and attitude signaling students to be more accepting of and comfortable with their differences. The more "others" are seen, heard and interacted with, the less inferior they appear, and the more normal and deserving of opportunities they become. 


\section{Racial Climate: The Psychology and Behavior of Faculty Members and Staff}

While racial climate is more often used to frame the experiences of students, it can also have a significant impact on faculty members' experiences and perceptions of the institution that might potentially affect their productivity, engagement, and satisfaction (Hurtado et al., 2010; Jayakumar, Howard, Allen, \& Han, 2009; Ponjuan, 2005; Turner \& Myers 2000; Turner, Gonzalez, \& Wood, 2008).

According to Stanley (2006), students often question the authority and knowledge of minority professors in the classroom. Black professors are viewed as being out of place and are not popularly identified as academics.

For example, in a study by Griffin et al. (2011), a black faculty member spoke of an encounter with another faculty member who assumed that he was a worker in facilities rather than a professor. The black faculty recounted "I remember walking into a classroom to meet a visiting scholar who was giving a talk, and when I walked in, someone who represented the group came up to me and asked me if I was there to move the furniture" (Griffin et al., 2011, Personal Racism Section, Para. 2).

Studies have shown that despite their leadership acumen, individuals from many racial and ethnic minorities will come up against ceilings and brick walls if institutions do not create an environment receptive of their contributions (Ahmed, 2012; Wolfe \& Freeman, 2013).

Sarsons (2015) found that women who coauthor papers with other faculty have lower tenure success rates and receive less credit for their intellectual contributions than do their male counterparts. For example, UCLA faculty complained that while male faculty who coauthored research papers with a senior coauthor received praise for doing high-quality work, female faculty who coauthored research papers with an established senior scholar received far less credit for contributing to the research (Korn, 2014). Additionally, tenure attainment rates for women are at the lowest when they coauthor only with men. The results are even lower when additional women are coauthors, thus leading one to conclude that gender bias may account for differences in promotion rates among men and women.

In a study in response to the question of whether women lose the advancement competition "because they lack quality points or because decision-makers perceive they lack this quality" (Van den Brink \& Benschop, 2012, p. 85), it was shown that female management faculty lose the competition because the process does not occur in a meritocracy.

Furthermore, it is perceived (without being grounded in evidence) that the records of women are inferior to those of men; thus, they face a lower 
probability of holding high positions than do male faculty members, even after controlling for performance, human capital factors, and other variables typically associated with advancement (Trevino, Gomez- Mejia, Balkin, \& Mixon, 2015). The 2009/2010 American Association of University Professors (AAUP) data indicated that women full-time faculty members were given lower salaries than were their male colleagues at all the traditional professorial ranks (professor, associate professor, and assistant professor), and in each institutional category (doctoral, master's, baccalaureate, and associate). Although women are approaching salary parity with men at community colleges, they still have a slight overall disadvantage (Mason, 2011).

Thus, it is clear that affirmative action policies to promote hiring of women in higher ranked positions are necessary to fight gender disparity, give credit to qualified women, and send a message that women belong in the academy. This would improve perception and behavior toward women faculty. Because historically women have been regarded as homemakers and caretakers, it takes a conscious and intentional effort to undo that kind of thinking, especially in an environment where hiring, promotion and tenure decisions are generally made by committees headed by males who buoy up each other and maintain business as usual.

It is important for institutions to establish policies where merit trumps the male gender advantage and where women are given the opportunity to shine a light on the quality of their scholarship. A conscious way of fostering inclusion of women is through affirmative action policies to hire women who are otherwise largely excluded. While race and gender conscious admission policies are helpful for minority representation, it is important to note that these policies must be developed and implemented within the law.

\section{Affirmative Action Policies: Historical and Legal Considerations}

As McLendon (2013) states, to have a better understanding of policy change, policy models should include time frames of a decade or longer. Historically, policies and legislative enactments have been put in place in attempts to grant access to underserved populations. However, such policies have not successfully created a level playing field for minorities.

In fact, educational policies have a history of being tainted by unfairness toward minorities. For example, while the 1862 and 1890 Morrill Acts were instituted to promote access to public higher education, it is reported that although all land-grant institutions were underfunded within this era, compared to their white counterparts, the seventeen black institutions were not proportionately equipped in facilities, salaries, and staffing. Hence, 
they did not have what it took to carry out advanced and original research (Thelin, 2011).

Additionally, the GI Bill (1944), which boosted postsecondary education opportunities for modest-income veterans, did not have a great impact on race relations at higher education institutions. While black veterans were eligible for the GI Bill, which helped to increase the enrollment of black students, the bill did not require participating institutions to exhibit nondiscrimination. In fact, the federal government did not penalize institutions that continued to exclude racial minorities. At the time of the bill, the US armed services still upheld policies of racial and ethnic discrimination. The economic benefits of educational opportunity had not yet been extended to concerns regarding civil rights. The "separate but equal" doctrine still prevailed (Thelin, 2011).

Wright and Garces (2018) posit that legal policies on affirmative action can have several origins, depending on historians' and scholars' perspectives. Like Wright and Garces (2018), this case also begins with

\section{Brown v. Board of Education.}

Brown v. Board of Education, Topeka, Kansas, 1954, was a combination of five nationwide cases in the struggle against racial discrimination, with plaintiffs specifically fighting for the desegregation of black and white public schools. The ruling established that segregation of public schools was "inherently unequal." The Supreme Court thus overturned the "Separate but Equal" doctrine (Bell, 2004; Bracey, 2013; Lewis, 2014; McNeil, 2005).

However, as was shown in discussions of minority representation and experiences in higher education above, the integration of education has not been fully achieved nor has equality between minorities and their dominant counterparts been reached. Hence, affirmative action policies are still necessary today to grant access to the underserved.

The term "affirmative action" in its modern connotation as a policy aimed at ensuring racial equality, was first used by the government in 1961 when President John F. Kennedy issued Executive Order 10925, which provided government contractors "... take affirmative action to ensure that applicants are employed, and employees are treated during employment, without regard to their race, creed, color, or national origin" (Mansky, 2016, para.13).

There are two types of affirmative action plans: remedial/mandatory plans and voluntary plans. The former comes from an order by a court or government agency that is justified only by serving as a remedy for, or dismantlement of, the current effects of past discriminatory actions 
perpetuated by the institution. The latter emerges from the conscious choice of the institution. Voluntary affirmative plans are justified by seeking to diminish the current consequences of past discriminatory practices and in order to attain and preserve the representation of a diverse student body, which is beneficial to educating the student body at large (Kaplin \& Lee, 2014).

Legal issues surrounding affirmative action can be categorized into constitutional and statutory manners for both private and public institutions.

- The constitutional issues stem from the Fourteenth Amendment's equal protection clause, where discriminatory treatments based on race, ethnicity, or sex, as well as "reversed discrimination" are generally prohibited within public institutions. This does not apply to public institutions.

- The statutory issues stem from Title VI of the Civil Rights Act of 1964 (which prohibits discrimination based on race, color, and national origin) and Title IX of the Education Amendments of 1972 (which prohibits sex discrimination). These issues are applicable to both public and private institutions that receive federal funding.

\section{The Law and Precedents: Student Admissions}

Regents of the University of California v. Bakke (1978) was the first modern Supreme Court case involving university affirmative action.

Allan Bakke, a white male, was denied admission twice to the medical school at the University of California at Davis. The school's special admissions program exclusively considered disadvantaged members of certain minority races for sixteen out of one hundred places in each year's class. The school's general admissions program allowed members of all races to qualify for the remaining eighty-four places. Under the general admissions program Bakke was denied, even though students with lower test scores had been admitted under the special admissions program. By a 5-to-4 vote, the Supreme Court invalidated the University of California Medical School's special admissions program, but through a different vote, the court ruled that some consideration of race is permissible in an affirmative action admissions plan (Wright \& Garces, 2018; Kaplin \& Lee, 2014). 
Justice Lewis F. Powell articulated three main principles in Bakke:

1. Racial/ethnic distinctions of all kinds -- regardless of whether they are intended to help or hurt intended beneficiaries -- were inherently suspect and thus called for "the most exacting judicial examination" (strict scrutiny). A strict scrutiny test requires institutions to demonstrate a "compelling interest" and means that are "narrowly tailored" to attain that interest.

2. Justice Powell established that the special admissions program in Bakke could not be justified to "assure within the student body a specified percentage of a particular racial group because that would be "discrimination for its own sake"; to counter the effects of "societal discrimination" because that was too broad for the government to address; or to increase the number of physicians who would practice in underserved communities because Powell opined there was no evidence to show that the special admissions program was either needed or geared toward that goal.

3. Justice Powell permitted the "diversity rationale", which supports making race one of several factors in the admissions process to promote the "educational benefits of diversity" (Wright \& Garces, 2018).

Perhaps of potential significance to proponents of affirmative action as a tool to promote racial diversity is Justice O'Connor's statement related to Bakke. "Although its precise contours are uncertain, a state interest in the promotion of racial diversity has been found sufficiently 'compelling', at least in the context of higher education, to support the use of racial considerations in furthering that interest" (Kaplin \& Lee, 2014, p. 200).

The 2003 Grutter v. Bollinger, and Gratz v. Bollinger cases are also of legal significance. In Gratz, the undergraduate admissions policy at the University of Michigan was based on a point system that automatically accorded 20 points to applicants from underrepresented groups. The Court found that this policy established race as the determinative admission factor for essentially all "minimally qualified" underrepresented minoritized applicants. The court pronounced that said policy was "not narrowly tailored" to attain the University of Michigan's propounded "compelling interest" in diversity. Thus, the court ruled it unconstitutional. In Grutter, on the other hand, when the Court reviewed the University of Michigan Law School's admissions program, it found the law school's plan focused on "academic 
ability" and employed "flexible" assessment of applicants' talents, experiences, and potential to contribute to the learning of those around them (Wright \& Garces, 2018).

The Supreme Court declared that the University of Michigan Law School's admissions plan did not define diversity exclusively in terms of race and ethnicity but deemed these as "plus" factors which affect overall diversity. For these reasons, in Grutter, unlike in the case of Gratz, the court held that the law school's admissions plan was narrowly tailored to further the school's compelling interest in attaining the educational benefits stemming from diversity. Bakke, Grutter, and Gratz, combined, "establish a core of comparable legal parameters for affirmative action, applicable to public and private institutions alike" (Kaplin \& Lee, 2014, p. 400).

In the case of Fisher v. University of Texas at Austin, Abigail Fisher, a white female, was rejected for the university's 2008 entering class. Five applicants of color with lower GPA and SAT scores were given admission ahead of Fisher (Cashin, 2014). Fisher argued in court that her race was the determining factor in her rejection, and that the university's consideration of race in admissions was a violation of the Equal Protection Clause of the Fourteenth Amendment. In the first round of Fisher (2013), the U.S. Supreme Court held that the trial court and court of appeals did not make the determination that no other alternative save race was necessary. Instead they seemed to defer to the university's judgment that it "needed" the use of race. Hence the Supreme Court established that the university adequately show that other "race-neutral" means did not produce the level of diversity needed. The court of appeals again held in favor of the university after the university applied the "correct" standard of strict scrutiny as instructed by the U.S. Supreme Court in Fisher I.

Abigail Fisher appealed and the Court agreed to hear the case a second time. This time (Fisher v. University of Texas II 2016), the U.S. Supreme Court in a 4-to-3 vote held that the University's race-conscious admission program met the "strict scrutiny" test. The university had indeed satisfactorily overcome the preference for race-neutral means, thus permitting its use of a race-conscious admissions practice (Wright \& Garces, 2018).

In the latest developments in affirmative action cases, Wright and Garces (2018) report that in November 2014, an organization named the Students for Fair Admissions filed lawsuits against Harvard University and the University of North Carolina at Chapel Hill claiming that both schools used race in their admissions processes in an unconstitutional manner. The plaintiffs were part of a group established by Edward Blum, who founded the 
Project on Fair Representation, a conservative organization whose objective is to eliminate all affirmative action-like policies in the U.S.

Students for Fair Admission and similar groups claim through their allegations that race-conscious admissions discriminate against Asian American students. They are challenging the usual Black-White binary through which the affirmative action debate is typically viewed. While research is still emerging on this issue, the literature shows that Asian American, African American, Latino, and White students are all beneficiaries of race-conscious admissions (Wright \& Garces, 2018). Additionally, their interests in supporting the policy are in alignment (Chu 2016; Lee 2015; Park \& Liu, 2014). Nevertheless, Students for Fair Admission continues its recruitment of Asian American students to challenge race-conscious admissions policies (Flanagan \& Xie, 2017; Gersen, 2017).

Collectively, the cases discussed provide legal precedents to inform and guide affirmative action policies. In Bakke, Justice Powell, writing on behalf of the majority, found that imposing the burden of history on the innocent would be unfair. The ruling meant that in making admission decisions, past discrimination of disadvantaged groups could no longer be considered. Hence, the burden of history would not be shared by all but rather solely shouldered by the victims of history. The decision apparently wiped the slate clean, as though history were disconnected from contemporary realities, and indicated that all people now operated on a level playing field (Newkirk, 2019). While quotas were regarded as unconstitutional, diversity was deemed a compelling state interest that enhanced the college environment at large. It meant that colleges could still consider race in admissions decision, but only as one of many factors in the process.

In the case of Grutter v. Bollinger, the Supreme Court's decision affirmed diversity as a compelling interest in college admissions but the Grutter decision was insufficient in helping universities to restore the progress gained during the civil-rights era (Newkirk, 2019). Following Bakke, universities have been compelled to steer clear of discussing past discrimination. Yet, avoiding the discussion of past discrimination is turning a blind eye to the crux of the issue, as history is responsible for the inequality universities desire to address today. The legacy of slavery and legal discrimination cannot be ignored in the battle for equality and inclusion of blacks (Newkirk, 2019; Hasnas, 2018; Dancy, Edwards \& Davis, 2018; Hurtado et al., 2010; Dumas, 2016; King, 2014).

The higher educational system which supports an advantageous hand for whites and a disadvantageous one for blacks is deeply rooted in history. Hence, affirmative action is needed to not only provide diversity to enrich the 
college experience but also to fix the problem of past deleterious discrimination that still affects the lived experiences of blacks today.

\section{AFFERNATIVE ACTION: FACULTY AND STAFF}

Race or gender-conscious faculty hiring and promotion decisions are perhaps just as controversial as affirmative action admissions plans. Those who benefit from affirmative action in areas of faculty and other professional areas are more noticeable due to the relative scarcity of faculty positions and the intense competition for them. Challenges surrounding hiring and promotion decisions are typically under federal or state employment discrimination laws. White plaintiffs allege "reverse discrimination" claiming that the college improperly used race, gender or some other protected characteristics in making employment decisions. When employers respond to the underrepresentation of women and other minority groups by giving preference to minority applicants (previously victimized) in lieu of other employees or applicants, it is viewed as discrimination "in reverse" (Kaplin \& Lee, 2014).

Affirmative action in employment is regulated by Executive Orders 11246 and 11375 and associated federal contracting statues, and by Title VII of the Civil Rights Act of 1964. It is also governed by the Equal Protection Clause of the Constitution's Fourteenth Amendment. The executive orders cover most colleges and universities as they meet the stipulation of having at least fifty or more employees and receiving federal contracts worth a minimum of $\$ 50,000$. The Equal Protection Clause is only applicable to public colleges and universities, while Title VII applies to both private and public colleges.

One requirement for affirmative action programs is "placement goals," which is established by contractors as relates to the availability of women and minorities for each job category. The placement goals are not to be rigid and inflexible quotas, nor should they establish ceiling and floor for the employment of specific groups. The U.S. Department of Labor's Office of Federal Contract Compliance Programs oversees institutional compliance with affirmative action requirements (Kaplin \& Lee, p. 193).

Public colleges and universities must provide a diversity rationale in any attempt to justify race or gender preferences in employment. To maximize the chances of success, the institution must demonstrate plainly how affirmative action-related hiring or promotion will enhance the benefits of educational diversity that the court would consider as compelling state interest as in the cases of Grutter and Gratz (Kaplin \& Lee, 2014). 


\section{THE LAW AND PROCEDURES: FACULTY AND STAFF HIRING}

According to Igwebuike (2006), the U.S. Supreme Court has not addressed diversity programs related specifically to faculty employment. Wygant v. Jackson Board of Education 1986 is the only Supreme Court case that deals directly with faculty and diversity. While Grutter, Gratz, and Bakke pertain to race-based affirmative action cases regarding diversity, Wygant is a race-based affirmative action case that pertains to the remediation of past discrimination.

In the case of Wygant v. Jackson Board of Education, a race-based layoff agreement was developed with the local teacher's union. According to that plan, in the occurrence of a layoff, teachers with the most seniority would be retained. The plan also specified that there would not be "a greater percentage of minority personnel laid off than the percentage of minority personnel employed at the time of the layoff' (Kaplin \& Lee, 2014, p. 199). The board laid off some white teachers with higher seniority than the minority teachers to meet the proportionality required by the agreement. The senior white teachers challenged the constitutionality of the agreement. The federal district court and the U. S Court of Appeals for the Sixth Circuit held that the provision was permissible, reasoning that the action was taken to remedy previous societal discrimination and to provide role models for minority children (Kaplin \& Lee, 2014).

The Supreme Court reversed that decision, in a 5-to-4 vote, concluding that the race-conscious layoff provision was in violation of the Equal Protection Clause. It was agreed that the agreement should be subjected to the "strict scrutiny" test. The plurality rejected the "societal discrimination" and "the role model" arguments. Having found no history of prior discrimination by the school board, they concluded that the board did not provide compelling interest as required by the strict scrutiny test. However, Justice Marshall found that the board's goal of preserving minority representation of teachers was a compelling interest based on the factual record presented to the court. Justice Marshall found the contractual provision narrowly tailored because it did not burden or benefit one race, rather it substituted a criterion different than absolute seniority for decisions regarding layoff (Kaplin \& Lee, 2014).

In a significant employment case, Weber v. Kaiser Aluminum Co. in 1979, a white steelworker challenged an affirmative action plan negotiated by his union and employer. The plan stated that for a new craft-training program, admission is based on one black worker for every white worker selected. The 
practice of this race-conscious plan would end when the proportion of black skilled craft workers at the plant reflected the proportion of black workers in the local labor force. In the first year of the program, several senior white workers were denied entry to the training program, but the most junior black worker was selected. A class action claim alleging "reverse discrimination" was filed by one of those denied (Kaplin \& Lee, 2014).

While the federal court ruled that the plan unlawfully discriminated against white employees and violated Title VII of the Civil Rights Act (affirmed by the appellate court), the Supreme Court reversed in a 5-to-2 decision. They ruled that private employers and unions may take raceconscious steps to eliminate "manifest racial imbalance"-- disparity in minority representation -- in traditionally segregated job types (Kaplin \& Lee, 2014). The court concluded that, given the intent of Title VII, voluntary efforts to achieve greater racial balance in the workforce was not in violation of the law. Thus, the use of racial preferences in hiring is sometimes permissible (Kaplin \& Lee, 2014).

Weber provides three factors that courts have used in subsequent cases to measure the lawfulness of affirmative action plans: first, the existence of a "manifest racial imbalance"; thus, discrimination in the past contributes to present imbalance; second, "traditionally segregated"; and third, the plan does not "unnecessarily trammel" the interests of white employees; it is a temporary means to bring minority representation up to that of others, but not to maintain a permanent racial balance (Kaplin \& Lee, 2014).

Collectively, Bakke, Gratz, and Grutter provide strong evidence upon which several tenable arguments can be made for extending the Court's student body diversity decision to faculty diversity contexts (Eckes, 2004). Despite the difficulty in translating the outcome in Grutter to the employment context, it seems that employers who can demonstrate a "manifest imbalance" and whose voluntary affirmative action plans pass the Weber test, might be able to apply affirmative action in decisions regarding hiring and promotion.

The lessons learned in the Grutter and Gratz cases should be heeded to ensure that affirmative action programs do not practice racial balancing or use quotas to achieve the goal of diversity. Considering the outcomes in Weber and Wygant, public and private universities alike should carefully analyze the effect of their affirmative action plans on existing and prospective non-minority faculty members to ensure that racial or gender preferences are not implemented in a manner that would "unnecessarily trammel" their interests (under Title VIII) or fail the test of strict scrutiny (under the federal equal protection clause) (Kaplin \& Lee, 2014). 
As Newkirk (2019) argues, mechanisms for targeted diversity hiring were created specifically because the normal hiring process did not yield diversity. It is common knowledge that higher education leadership and faculty search committees are typically chaired by white males (Loyd-Jones, 2019; Abdul-Rahem, 2016; Collins, 2014; Korn, 2014; Quaye, 2012) whose values, backgrounds, and scholarly interests mirror those of the candidates they deem fit for the job. In addition to the process being subjective, some leaders of higher ranking make powerful moves to bring in their desired candidates; hence the hiring process becomes a show of formality.

To ensure equal representation, it is important for higher education institutions to be intentional about building a diverse faculty. However, intentional measures such as targeted hiring have the propensity to provoke resentment among some white faculty members who regard the process as giving minorities preferential treatment (Newkirk, 2019) or that the bar is being lowered for underrepresented scholars who would otherwise be overlooked. Hence, it is important to include legal experts when establishing affirmative action policies.

In addition to subjectivity in the hiring process, where diversity is of high priority, institutions tend to hire from the same pool of prominent scholars in their field, which poses a problem for emerging scholars of color who are then overlooked. Consequently, colleges recycle the same prominent scholars of color, leaving the overall number of underrepresented faculty members unchanged - a system that for decades has sustained the status quo (Newkirk, 2019). To rely on the normal hiring process to realize the representation of underserved faculty members would be inadequate; it would not address the need for diversity and inclusion or bridge the gap between the white faculty members, who have historically dominated the academy, and minority faculty, who were excluded in the past and still are today. Hence, affirmative action policies established within the guidelines of the law are still proper and necessary today.

\section{FINAL ARGUMENT/CONCLUSION}

For those color-blind proponents who contend that affirmative action bans have not changed student diversity, Kurlaender, Friedmann, and Chang (2015) demonstrate that bans on affirmative action have led to a decrease in racial diversity and have further stratified postsecondary education, with students of color attending less selective institutions than their counterparts. For example, after bans on affirmative action were implemented in California, Florida, Texas, and Washington, there was a decline in the enrollment of 
underrepresented students of color at selective undergraduate universities (Backes 2012; Hinrichs 2012).

To debunk the color-blind proponents' support of the mismatch theory, a significant amount of social science research show that mismatch effects are small or hardly exist. In fact, they might suggest the reverse of mismatch (Wright \& Garces, 2018). For example, Kidder and Lempert (2015) state that students of color are likely to perform better when they attend more selective institutions.

For the race-neutral camp who propose proxies of race, studies have shown that race-neutral alternatives do not in fact yield the same benefits of racial and ethnic diversity as would the consideration of race in admissions programs (Kidder 2016; Long, 2015). It is argued that socioeconomic statusbased affirmative action policies do not produce nearly as much racial diversity as race-based policies, nor do they work in combination with race and class considerations (Carnevale, Rose \& Strohl, 2014; Reardon, Baker, Kasman, Klasik, \& Towsend, 2015). While some race-neutral alternatives may be easier for the public to digest, they are not necessarily effective in comparison to race-conscious admissions (Wright \& Garces, 2018).

It is important that institutions acknowledge and shed light on their history of exclusion, which might lead to more support for affirmative action plans. Institutions must identify "embedded benefits" for specific groups and clearly articulate a vision for a more inclusive campus. That a better understanding of how the campus racial climate affects minority faculty and students is critical in recruiting, retaining, and supporting minorities in academia. We know that diversity enhances the classroom learning environment; it supports cross-cultural understanding; it strengthens America's economic competitiveness; and it helps all to become aware of the values of democratic governance (Hasnas, 2018; Hurtado et al., 2010; Grifin et al. 2011).

In conclusion, the best way to help in creating equality for historically minoritized populations and to capture, nurture, and maintain diversity on a college campus is through race-conscious admissions (Jayakumar \& Garces, 2015). In addition to the guidelines discussed in the cases, it is reinforced, in accordance with Kaplin and Lee's (2014) recommendations, that administrators should have legal counsel fully involved when considering adopting or revising affirmative action admissions programs. Moreover, an institution must demonstrably rely on the educational expertise of its faculty and academic administrators as well as on the acts of the policy makers at the top of its hierarchy, those with the highest authority. The university must 
ensure that decisions are made in context of the institution's purposes and objectives, in the light of its stated educational mission.

\section{REFERENCES}

Abdul-Raheem, J. (2016). Faculty Diversity and Tenure in Higher Education. Journal of Cultural Diversity, 23(2), 53-56. Retrieved from http://search.ebscohost.com.proxy-

ms.researchport.umd.edu/login.aspx?direct $=$ true $\& d b=$ mnh $\& A N=2743923$ $1 \&$ site $=$ eds-live \&scope $=$ site

Adams, M., Blumenfeld, W. J., Castañeda, R., Hackman, H. W., Peters, M. L., \& Zúñiga, X. (Eds.). (2013). Readings for diversity and social justice ( $3^{\text {rd }}$ ed.). New York: Routledge

Ahmed, S. (2012). On Being Included: Racism and Diversity in Institutional Life. Durham and London: Duke University Press.

American Council on Education (2017) Overview. Retrieved from http://www.aceacps.org/minority-presidents/

Associated Press (Producer). (2018). AP explains: Trump on race-based school admissions [Streaming video]. Retrieved from Associated Press Video Collection database.

Backes, B. (2012). Do Affirmative Action Bans Lower Minority College Enrollment and Attainment? Evidence from Statewide Bans. Retrieved from http://econ2.econ.iastate.edu/classes/econ321/orazem/backes 2012 affirm ative action.pdf

Bailyn, L. (2003). Academic careers and gender equity. Lessons learned from MIT. Gender, Work \& Organization, 10: 137-153. Retrieved from https://onlinelibrary.wiley.com/doi/abs/10.1111/1468-0432.00008

Basinger, J. (November/December 2016) Campus Unrest. AGB Trusteeship, 24 (6), $8-13$.

Bell, D. (2004). Silent Covenants: Brown v. Board of Education and the Unfulfilled Hopes for Racial Reform (Book). Booklist, 100(15), 1334. Retrieved from http://search.ebscohost.com.proxyms.researchport.umd.edu/login.aspx?dire

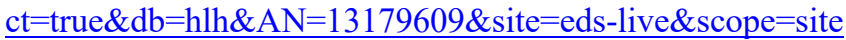

Blanchard, J. (2018). Controversies on Campus: Debating the Issues Confronting American Universities in the 21st Century. Retrieved from http://publisher.abc-clio.com/9781440852206

Blackwell, J. E. (1988). Faculty Issues: The Impact on Minorities. The Review of Higher Education 11(4), 417-434. Johns Hopkins University Press. Retrieved January 22, 2019, from Project MUSE database.

Bracey, N. (2013). Brown vs. Board of Education and the Unfulfilled Hopes for Racial and Educational Reform: A Political Analysis of Derrick Bell's Silent Covenants. International Journal of Business and Social Research, 3(10), 13-20. doi:http://dx.doi.org/10.18533/ijbsr.v3i10.302

Brown, M.C. (2010). Organization and governance in higher education $\left(6^{\text {th }}\right.$ ed $)$. Boston: Pearson Custom Publishing 
Carnevale, A.P., Rose, S., \& Strohl, J. (2014) Achieving Racial and Economic Diversity With Race-Blind Admissions Policy, in The Future Of

Affirmative Action: New Paths To Higher Education Diversity After Fisher V. University Of Texas 187 In Richard D. Kahlenberg (ed.).

Cashin, S. (2014). Place not race: A new vision of opportunity in America. Beacon Press. Retrieved from http://www.beacon.org/Place-Not-Race-P1106.aspx

Cataldi, E. F., Bradburn, E. M., Mansour, F., \& Zimbler, L. (2005). "2004 National Study of Postsecondary Faculty: Background Characteristics, Work Activities, and Compensation of Instructional Faculty and Staff; Fall 2003." Report, NCES 2006-176, U.S. Department of Education, Washington, DC.

Chu, C. H. (2016). When Proportionality Equals Diversity: Asian Americans and Affirmative Action, 23 Asian American Law Journal. Retrieved from https://scholarship.law.berkeley.edu/cgi/viewcontent.cgi?article=1220\&co ntext=aalj

Collins, P. (2014). Black feminist thought. New York, NY: Routledge.

Collins, S.M. (2002). Organizational response to affirmative action. In Durr, M.

(ed.) The New Politics of Race: From DuBois to the 21st Century.

Dancy, T. E., II, Edwards, K. T., \& Earl Davis, J. (2018). Historically White

Universities and Plantation Politics: Anti-Blackness and Higher Education in the Black Lives Matter Era. Urban Education, 53(2), 176-195. Retrieved from http://proxy-

tu.researchport.umd.edu/login?ins=tu\&url=http://search.ebscohost.com/log in.aspx?direct $=$ true $\& \mathrm{db}=$ eric $\& \mathrm{AN}=\mathrm{EJ} 1167388 \&$ site $=$ eds-live \&scope $=$ site

Darling-Hammond, L. (2015). The flat world and education: how America's commitment to equity will determine our future. New York: Teachers College Press.

Delgado, R., \& Stefancic, J. (2012). Critical race theory: An introduction. New York: New York University Press.

Dowd, A. C., \& Bensimon, E. M. (2015). Engaging the "Race Question": Accountability and Equity in U.S. Higher Education (Multicultural Education Series). New York: Teacher's College Press.

Dumas, M. J. (2016). Against the dark: Antiblackness in education policy and discourse. Theory into Practice, 55, 11-19.

Duncan Kennedy (1990), A Cultural Pluralist Case for Affirmative Action in Legal Academia, Retrieved from 1990 DUKE L.J. 705, 715 (1990).

Eckes, S. E. (2004). Race-conscious admissions programs: Where do universities go from Gratz and Grutter? Journal of Law \& Education, 33, 21-62.

Eckel, P. D., \& Trower, C.A. (2016). Boards and institutional diversity: Missed opportunities, points of leverage. New York, NY: TIAA Institute.

Exum, W. H., Menges, R.J, Watkins, B., \& Berglund, P. (1984). "Making It at the Top: Women and Minority Faculty in the American Labor Market." American Behavioral Scientist 27 (3): 301-24. 
Flanagan, W.S., \& Xie, M. E. (2017). Median Family Income for Harvard Undergrads Triple National Average, Study Finds. Retrieved from https://www.thecrimson.com/article/2017/1/25/harvard-income-percentile/

Fryer, R.G., \& Loury, G.C. (2005). "Affirmative Action and Its Mythology." Journal of Economic Perspectives, 19 (3): 147-162.

Garces, L.M., \& Mickey-Pabello, D. (2015) Racial Diversity in the Medical Profession: The Impact of Affirmative Action Bans on Underrepresented Student of Color Matriculation in Medical Schools, The Journal of Higher Education, 86:2, 264-294, DOI: 10.1080/00221546.2015.11777364.

Gersen, J. S. (2017). The Uncomfortable Truth About Affirmative Action and AsianAmericans. The New Yorker. Retrieved from https://www.newyorker.com/news/news-desk/the-uncomfortable-truthabout-affirmative-action-and-asian-americans

Griffin, K.A, Pifer M. J., Humphrey, J.R., \& Hazelwood, A. M., (2011) "(Re)Defining Departure: Exploring Black Professors' Experiences with and Responses to Racism and Racial Climate," American Journal of Education 117, no. 4 (August 2011): 495-526. https://doi-org.proxy$\underline{\text { ms.researchport.umd.edu/10.1086/660756 }}$

Harpalani, V. (2012). Diversity Within Racial Groups and the Constitutionality of Race-Conscious Admissions. Penn Law Legal Scholarship Repository 15 U. Pa. J. Const. L. 463.

Harper, S. R., (2012, Fall Supplement). Race without Racism: How higher education researchers minimize racist institutional norms. The Review of Higher Education, 36(1): 9-27.

Harper, S.R., \& Quaye, S.J. (Eds.) (2015). Student engagement in higher education: Theoretical perspectives and practical approaches for diverse populations. New York, NY: Routledge.

Hasnas, J. (2018). The Ethics of Diversity: The Georgetown Institute for The Study of Markets and Ethics: Diversity in The University and Business: The Quest for a Diverse Faculty: Theory and Practice. Georgetown Journal of Law \& Public Policy, 16, 753. Retrievedfrom https://advance-lexiscom.proxyms.researchport.umd.edu/api/document?collection=ana lytical-materials\&id=urn:contentItem:5TV0-5BS0-0198-G0WT$\underline{00000-00 \& \text { context }=1516831}$

Hendricks, A. D. \& Caplow, J. A. (1998). "African American Faculty Perceptions of the Academic Culture and Their Professional 
Socialization." Paper presented at the Association for the Study of Higher Education annual meeting, Miami.

Hinrichs, P. (2012). "The Effects of Affirmative Action Bans on College Enrollment, Educational Attainment, and the Demographic Composition of Universities," The Review of Economics and Statistics, MIT Press, vol. 94(3), pages 712-722.

Hinrichs, P. (2014). "Affirmative Action Bans and College Graduation Rates," Economics of Education Review, vol.42, 43-52. Retrieved from

https:/www.sciencedirect.com/science/article/pii/S027277571400 $\underline{0624}$

History - Brown v. Board of Education Re-enactment, United States Courts. Brown v. Board of Education, The Civil Rights Movement: Volume I (Salem Press).

Hurtado, S. (1992), "The Campus Racial Climate: contexts of conflict", The journal of Higher Education, Ohio State University Press

Hurtado, S., Milem, J.F., Clayton-Pedersen, A. R., \& Allen, W. R. (2010). Enhancing Campus Climates for Racial/Ethnic Diversity: Educational Policy and Practice. In M.C. Brown (Ed) Organization \& Governance in Higher Education. (pp. 295-309). Pearson Custom Publishing, Boston, MA

Hurtado, S., \& Ruiz, A. (2012). The Climate for Underrepresented Groups and Diversity on Campus. Higher Education research institute at UCLA. Retrieved from https://www.heri.ucla.edu/briefs/URMBriefReport.pdf

Igwebuike, J. G. (2006). Legal and Policy Implications for Faculty Diversification in Higher Education. Negro Educational Review, 57(3/4), 189-201. Retrieved from

http://search.ebscohost.com.proxyms.researchport.umd.edu/login.aspx?dire $\underline{\mathrm{ct}=\text { true } \& \mathrm{db}=\mathrm{tfh} \& \mathrm{AN}=24477217 \& \text { site }=\text { eds-live } \& \text { scope }=\text { site }}$

Jayakumar, U., Howard, T. C., Allen, W. R, \& Han, J. C. (2009). "Racial Privilege in the Professoriate: An Exploration of Campus Climate, Retention, and Satisfaction." Journal of Higher Education 80 (5): 538-63.

Jayakumar, U. \& Garces, L. M. (2015). Affirmative Action and Racial Equity: Considering the Fisher Case to Forge. New York: Routledge. 
Johnson, K.R (2011), The Importance of Student and Faculty Diversity in Law Schools: One Dean's Perspective, 96 IOWA L. REV. 1549, 1560 (2011).

Johnsrud, L. K. \& DesJarlais, C.D. (1994). "Barriers to Tenure for Women and Minorities." Review of Higher Education 17 (4): 335-53.

Kahlenbergh, R., \& Potter, H. (2014). Class-based Affirmative Action Works. The New York Times. Retrieved from https://www.nytimes.com/roomfordebate/2014/04/27/should-affirmativeaction-be-based-on-income/class-based-affirmative-action-works

Karabel, J. (1998). No alternative: The effects of color-blind admissions in California. In G. Orfield \& E. Miller (Eds.), Chilling admissions: The affirmative action crisis and the search for alternatives (pp. 3350). Cambridge, MA: Harvard Education Press.

Kaplin, W. A., \& Lee, B. A. (2006). The law of higher education: A comprehensive guide to legal implications of administrative decision making (4th Ed.). San Francisco: Jossey-Bass.

Kidder, W. C. (2016). How Workable Are Class-Based and Race-Neutral Alternatives at Leading American Universities? UCLA Law Review. Retrieved from https://www.uclalawreview.org/wpcontent/uploads/2016/06/Kidder-D64-update.pdf

Kidder, W. C. (2013), Policy Brief, Restructuring Higher Education Opportunity?: African American Degree Attainment After Michigan's Ban on Affirmative Action. Retrieved from http://papers.ssrn.com/sol3/papers. cfm?abstract_id=2318523 [https://perma.cc/BX5P-8H5Z].

Kidder, W. C., \& Lempert, R. O. (2015). The mismatch myth in U.S. higher education. In U. M. Jayakumar \& L. M. Garces (Eds.), Affirmative action and racial equity: Considering the Fisher case to forge the path ahead (pp. 105-129). New York, NY: Routledge.

King, T. (2014). Labor's aphasia: Toward antiblackness as constitutive to settler colonialism. Decolonization, Indigeneity, Education \& Society. Retrieved from https://decolonization.wordpress.com/2014/06/10/labors-aphasiatoward-anti- blackness-as-constitutive-to-settler-colonialism/

Korn, M. (2014). Gender bias alleged at UCLA's Anderson Business School. Wall Street Journal. Retrieved from: www. online.wsj.com/articles/gender-biasalleged-at-uclas-anderson- business- school-1401924672 
Kurlaender, M., Friedmann, E., \& Chang, T. (2015). Access and Diversity at the University of California in the Post-Affirmative Action Era. Retrieved from https://books.google.com/books?id=atEqBwAAQBAJ\&pg=PA80\&lpg=P A80\&dq $=$ kurleander + friedman + and + chang + affirmative + action\&source $=b l$ \&ots=1lhGLkdWv \&sig=ACfU3U0i1MN6oNRPgiFyPTKmF7chwxH88g \&hl=en\&sa $=$ X\&ved=2ahUKEwj3ue3G1JDgAhUym-

AKHdiHDvoQ6AEwDnoECAQQAQ $\# \mathrm{v}=$ onepage\&q $=$ kurleander $\% 20$ fried man\%20and\%20chang\%20affirmative $\% 20$ action \&f=false

Ladson-Billings, G. \& Tate, W. (1995). "Toward a Critical Race Theory of Education." Teachers College Record 97 (1): 47-68.

Ladson-Billings, G. (1998). “Just What Is Critical Race Theory and What Is It Doing in a Nice Field like Education?" Qualitative Studies in Education 11 (1): 7 24.

Lee, B. (2015) Affirmative Action. Wiley Online Library. Retrieved from https://onlinelibrary.wiley.com/doi/abs/10.1002/9781118785317.weom050 $\underline{157}$

Lewis, T. T. (2014). Brown v. Board of Education. Salem Press Encyclopedia. Retrieved from http://search.ebscohost.com.proxyms.researchport.umd.edu/login.aspx?direct $=$ true $\& d b=e r s \& A N=95329247$ $\underline{\& \text { site }=\text { eds-live } \& \text { scope }=\text { site }}$

Long, M. C. (2015). Is there a "workable" race-neutral alternative to affirmative action in college admissions? Journal of Policy Analysis and Management, $34,162-183$.

Lloyd-Jones, B. (2019). Where are the African American Women Leaders? A Call for More Nuanced Research in Higher Education, International Journal of Humanities and Social Science, Research Institute for Progression of Knowledge Review; Vol. 5 No. 1 ISSN 2415-1157 Retrieved from http://www.ijhssrnet.com/wp-content/uploads/2019/02/2.pdf

Mansky, J. (2016). The Origins of the Term “Affirmative Action.” Smithsonian.com. Retrieved from https://www.smithsonianmag.com/history/learn-originsterm-affirmative-action-180959531/ 
Mason, M.A. (2011). The Pyramid Problem. The Chronicle of Higher Education. Retrieved from https://www.chronicle.com/article/The-PyramidProblem/126614

McNeil, G.R. (2005). Silent Covenants: Brown v. Board of Education and the Unfulfilled Hopes for Racial Reform Derrick Bell. The Journal of Southern History, (4), 947.

https://doi-org.proxy$\underline{\text { ms.researchport.umd.edu/10.2307/27648971 }}$

McLendon, M.K. (2003). The politics of higher education: Toward an expanded research agenda. Educational Policy, 17 (1), 165-19.

Miller, C. (2019). Affirmative Action and Its Persistent Effects: A New Perspective. California Management Review, 61(3), 1933. https://doi.org/10.1177/0008125619849443

Newkirk, P. (2019, November). Why Diversity Initiatives Fail. The Chronicle Review: The Chronicle of Higher Education. Section B, B6-B9

Nguyen, B. (2019). Affirmative Action in the Trump Era. Fam Med. 2019;51(9):719721. https://doi.org/10.22454/FamMed.2019.637810.

Park, J., \& Liu, A. (2014). Interest Convergence or Divergence? A Critical Race Analysis of Asian Americans, Meritocracy, and Critical Mass in the Affirmative Action Debate. Journal of Higher Education. v85 n1 p36-64. Retrieved from https://eric.ed.gov/?id=EJ1034007

Perlmutter, D. D. (2013). Know the vital players in your career: The tenured factions. The Chronicle of Higher Education. Retrieved from: www.chronicle.com/article/Know- the-Vital- Players-in-Your/142887/

Perna, L. W. (2002). Racial and Ethnic Group Differences in College Enrollment Decisions. Retrieved from https://onlinelibrary.wiley.com/doi/abs/10.1002/ir.10705

Perna, L.W. (2000). Differences in the decision to enroll in college among African Americans, Hispanics, and whites. Journal of Higher Education, 71, 117141.

Ponjuan, L. (2005). "Understanding the Work Lives of Faculty of Color: Job Satisfaction, Perceptions of Climate, and Intention to Leave." $\mathrm{PhD}$ diss., University of Michigan. 
Prescott, B. T., \& Bransberger, P. (2012). Knocking at the College Door: Projections of High School Graduates ( $8^{\text {th }}$ edition). Boulder, CO: Western Interstate Commission for Higher Education.

Quaye, S. J. (2012). White Educators Facilitating Discussions About Racial Realities. Equity and Excellence in Education, 45(1), 100-119.

Quinlan, C. (2016). 5 Things That Make It Hard To Be A Black Student At A Mostly White College. Retrieved November 13, from https://thinkprogress.org/5-things-that-make-it-hard-to-be-ablack-student-at-a-mostly-white-college33ef44abe034\#.16awh2noj

Reardon, S. F., Baker, R., Kasman, M., Klasik, D., \& Townsend, J. B. (2015). Can socioeconomic status substitute for race in affirmative action college admissions policies? Evidence from a simulation model (Issue Brief). Princeton, NJ: Educational Testing Service.

Richeson, J. A., \& Nussbaum, R. J. (2004). The impact of multiculturalism versus color-blindness on racial bias. Journal of Experimental Social Psychology, 40(3), 417-423. https://doi.org/10.1016/j.jesp.2003.09.002

Ridgeway, C. L. (2007). Gender as a group process: Implications for the persistence of inequality. In S. J. Connell (Ed.), Social psychology of gender: 311-333, Bingley, UK: Emerald Group Publishing.

Ryu, M. (2008). Minorities in Higher Education 2008: Twenty-third Status Report. Washington, DC: American Council on Education.

Sarsons, H (2015). Gender differences in recognition for group work. Retrieved from: www.gender groupwork.pdf

Schmidt, P. (2013). At the Elite Colleges. In Adams et al. (Eds.). Readings for diversity and social justice (3rd ed.). New York: Routledge.

Schuck, P. H. (2002). Affirmative Action: Past, Present, and Future. Yale Law \& Policy Review: Vol. 20 : Iss. 1 , Article 2 retrieved from https://digitalcommons.law.yale.edu/ylpr/vol20/iss1/2/

Stanley, C. A. (2006). "Coloring the Academic Landscape: Faculty of Color Breaking the Silence in Predominantly White Colleges and Universities." American Educational Research Journal 43 (4): 701-36. 
Thelin, J. R. (2004). A history of American higher education. Baltimore: Johns Hopkins University Press.

Thomason, A. (2018). Trump Administration Will Rescind Obama-Era Guidelines on Race-Conscious Admissions, retrieved from https://www.chronicle.com/article/Trump-Administration-Will/243828

Trevino, L.J., Balkin, D.A., Gomez-Mejia, L.R. (2017). How doing gender leads to gender imbalances in higher ranks in colleges of business and how to undo gender. Academy of Management Learning \& Education, 16(3), 439-453.

Trevino, L. J., Gomez-Mejia, L. R., Balkin, D., \& Mixon, F. G., Jr. (2015). Meritocracies or masculinities? The differential allocation of named professorships by gender in the academy. Journal of Management, 1-29. doi: $10.1177 / 0149206315599216$.

Trower, C. A. \& Chait, R. P. (2002). "Faculty Diversity: Too Little for Too Long." Harvard Magazine (March-April): 33-37.

Turner, C. S. V., Gonzalez, J. C, \& Wood, L. (2008). "Faculty of Color in Academe: What 20 Years of Literature Tells Us." Journal of Diversity in Higher Education 1 (3): 139-68.

Turner, C. S. V. \& Myers, S. L. (2000). Faculty of Color in Academe: Bittersweet Success. Boston: Allyn \& Bacon.

United Negro College Fund: Public Policy and Government Affairs. (2017). Public Policy Priorities for the Trump Administration and the 115th Congress. Washington

DC:

UNCF. Retrieved from https://morgan.blackboard.com/courses/1/78984.201870/db/ $1193726 \quad 1 / 2$ 017 UNCF PublicPolicyPriorities for the 115th Congress Final 7.12.17.pdf

Van den Brink, M., \& Benschop, Y. (2012). Slaying the seven-headed dragon: The quest for gender change in academia. Gender, Work and Organization, 19(1): 71-92.

Watkins, W. H. (2001). The White Architects of Black Education: Ideology and Power in America, 1865-1954. New York: Columbia University Teacher's College Press.

Wilder, C. S. (2013). Ebony \& Ivy: Race, Slavery, and the Troubled History of America's Universities. New York: Bloomsbury Press. 
Wolfe, B., \& Freeman, S. (2013). A Case for Administrators of Color: Insights and Policy Implications for Higher Education's Predominantly White Institutions. ejournal of Education Policy. Retrieved from https://eric.ed.gov/?id=EJ1158580

Wright, D. K., \& Garces, L. M. (2018). Understanding the Controversy around RaceBased Affirmative Action in American Higher Education. In J. Blanchard (Ed), Controversies on Campus: Debating the Issues Confronting American Universities in the $21^{\text {st }}$ Century, Retrieved from http://publisher.abcclio.com/9781440852206

Zinn, H. (2003). A people's history of the United States. New York: Harper \& Row.

ANGEL WAZIN is a PhD candidate in the Higher Education Administration Program at Morgan State University. She works as a graduate assistant and support staff in the Office for Academic Affairs. Her research interest is in the areas of social justice, race, and gender. Contact her at anwaz1@morgan.edu. 